\title{
MEDICINOS DARBUOTOJŲ ŽINIOS APIE INFEKCIJŲ VALDYMĄ SVEIKATOS PRIEŽIŪROS İTAIGOSE
}

\author{
Jonas Kairys ${ }^{1,2}$, Renata Šturiene $\dot{e}^{1,2}$, Miglė Lamanauskaité ${ }^{1}$, Valerij Dobrovolskij ${ }^{1,2}$ \\ ${ }^{1}$ Vilniaus miesto Šeškinès poliklinika, ${ }^{2}$ Vilniaus universiteto Medicinos fakultetas
}

Raktažodžiai: medicinos darbuotojai, hepatitas B, mikrotrauma, infekcijų valdymas, žinios.

\begin{abstract}
Santrauka
Tyrimo tikslas - įvertinti medicinos darbuotojų žinias apie infekcijų valdymą, ịvertinti vakcinacijos apimtis nuo hepatito B viruso bei mikrotraumų paplitimą tarp VšI Šeškinès poliklinikos (toliau - Poliklinika) medicinos darbuotojų. Buvo atlikta medicinos darbuotojų anketinè apklausa. Respondentų buvo klausiama apie rankų higieną, dezinfekciją, sterilizaciją, mikrotraumas bei skiepijimus hepatito B vakcina. Išdalintos 305 anketos, grąžinta 251 anketa (atsako dažnis 82,3 proc.). Iš jų tinkamos analizei - 243 anketos. 68,7 proc. tiriamujų turi pakankamai žinių aseptikos/antiseptikos klausimais. 33,3 proc. respondentų buvo susižeidę panaudota adata ar kitu aštriu instrumentu. Iš jų 28,4 proc. nurodè, kad buvo susižeidę užteršta priemone, t.y. priemone, kontaktavusia su pacientu ar užterštu įrenginiu. Tyrimo metu nustatyta, kad su 2,03 karto didesniu šansu bendrosios praktikos slaugytojos patiria mikrotraumas nei kitų sričių specialistai. 40,7 proc. respondentų nurodè, kad buvo pasiskiepiję hepatito B vakcina. Respondentai, dirbantys Odontologijos skyriuje, su 5,62 didesniu šansu dažniau skiepijasi nuo hepatito B nei respondentai, dirbantys kituose Poliklinikos skyriuose.
\end{abstract}

\section{Ivadas}

Nepaisant šiuolaikinių infekcijų kontrolès ir prevencijos priemonių, su sveikatos priežiūra susijusios infekcijos ir toliau išlieka svarbi asmens ir visuomenès sveikatos problema [1-2]. Medicinos personalo rankos - vienas svarbiausių rizikos veiksnių pernešant mikroorganizmus nuo vieno asmens kitam gydymo įstaigose [3]. Per rankas perduodami mikroorganizmai tampa hospitalinių infekcijų priežastimi. Europos ligu prevencijos ir kontrolès centras (angl. European Centre for Disease Prevention and Control, ECDC), apibendrinęs Europoje ir Kanadoje atliktų paplitimo tyrimų duomenis, paskelbe, kad vidutinis hospitalinių infekcijų paplitimas ekonomiškai stipriose šalyse yra apie 7 proc. ir svyruoja nuo 3,5 iki 10,5 proc. [4]. Bendras hospitalinių infekcijų paplitimas Lietuvos ligoninèse - nuo 3,9 proc. (2010 m.) iki 4,3 proc. $(2014 \mathrm{~m}$.) $[3,5]$.

Iš visų virusinių hepatitų didžiausią problemą sudaro hepatitas B (toliau - VHB). Sergamumas ūmiais VHB bendroje populiacijoje per pastaruosius šešerius metus (2009-2015 m.) Lietuvoje sumažèjo nuo 1,7 iki 1,1 atvejų 100 tūkst. gyventojų, o sergamumas ūmiais virusiniais hepatitais C (toliau - VHC) sumažejo nuo 1,4 iki 0,8 susirgimo atvejo 100 tūkst. gyventojų [6]. VHB yra skiepais valdoma infekcija ir daugumai užsikrètusiujjų šia infekcija nepasireiškia jokie ligos požymiai $(50-70$ proc. - VHB ir $60-70$ proc. - VHC yra besimptominiai). Tai ypač aktualu, nes Lietuva priklauso vidutinio endemiškumo zonai, o tai reiškia, kad HBsAg paplitimo lygis siekia 2-7 proc. [7-8]. Patikima apsaugos nuo VHB infekcijos priemonė yra vakcinacija. Didelès rizikos užsikrèsti VHB asmenys turètų būti skiepijami (nuteistieji, medikai, ŽIV infekuoti ir kt.). Istaigos vadovas, vadovaudamasis Lietuvos Respublikos sveikatos apsaugos ministro $2004 \mathrm{~m}$. spalio $14 \mathrm{~d}$. isakymu Nr. V-716 „Dèl darbuotojų, kurie skiepijami darbdavio lèšomis, profesijų ir pareigybių sąrašo patvirtinimo" (Žin., 2004; 155-5664), turi raštu pasiūlyti nemokamai pasiskiepyti nuo virusinio hepatito B [9].

Medicinos darbuotojai dèl kasdienio kontakto su žmogaus organizmo skysčiais priskiriami didžiausios biologinių veiksnių rizikos grupei. Mikrotrauma - tai susižeidimas naudotais aštriais instrumentais, aštriais daiktais, užterštais kito asmens krauju ar biologiniais skysčiais [10]. Ekspozicijos biologiniais skysčiais ir mikrotraumų rizika yra susijusi su infekcijomis, plintančiomis krauju: hepatito B virusu (HBV), hepatito C virusu (HCV), žmogaus imunodeficito virusu (ŽIV), herpetiniais virusais, sifiliu, tuberkulioze ir kt. [11].

Tikslas - įvertinti medicinos darbuotojų žinias apie infekcijų valdymą, ịvertinti vakcinacijos apimtis nuo hepa- 
tito B viruso bei mikrotraumų paplitimą tarp Poliklinikos medicinos darbuotojų.

\section{Tyrimo medžiaga ir metodai}

Siekiant ịvertinti medicinos darbuotojų žinias infekciju kontrolès klausimais, 2015.12 - 2016.03 metais Poliklinikoje atliktas momentinis (paplitimo) tyrimas. Tyrimo metodas - anketinè apklausa. Anketą sudarè dokumentinė ir specialioji dalis. Dokumentineje dalyje pateikti klausimai apie darbuotojų lytį, amžių, pareigas ir darbo stažą. Specialiojoje dalyje pateikti klausimai apie infekcijų valdymą asmens sveikatos priežiūros ịstaigose (toliau - ASPI), mikrotraumų dažni, vakcinaciją hepatito B vakcina. Tiriamųjų grupę sudare Poliklinikos vienuolikos skyrių darbuotojai, kurie buvo atrinkti atsitiktinès atrankos būdu. Išdalytos 305 anoniminès anketos, grąžinta 251 anketa (atsako dažnis 82,3 proc.). Keletas anketų buvo sugadintos. Galutinei duomenų analizei panaudotos 243 anketos.

Statistiniam duomenu apdorojimui naudojama SPSS 17.0 versija bei WinPepi, OpenEpi kompiuterinès programos. Skirtumui tarp grupių ịvertinti taikytas Pearson'o chikvadrato testas, Fisher's tikslusis metodas. Rodiklių skirtumai buvo laikomi statistiškai reikšmingais, kai $\mathrm{p}<0,05$. Tolydiesiems kintamiesiems buvo naudojami standartiniai aprašomosios statistiskos rodikliai: parametru aritmetinis vidurkis, standartinis nuokrypis, mediana, minimali bei maksimali reikšmė. Kategorinių duomenų ryšio analizei buvo skaičiuojamas šansų santykis (OR). Ranginių kintamụjų sąsajoms nustatyti naudota Spearman'o koreliacija. Anketos rezultatai pateikiami diagramose ir lentelese.

\section{Rezultatai}

Tyrime dalyvavo 243 Poliklinikos medicinos darbuotojai. Iš jų 87,2 proc. $(n=212)$ moterų ir 12,8 proc. $(n=31)$ vyrų. Vidutinis respondentų amžius buvo 50 metų (min -

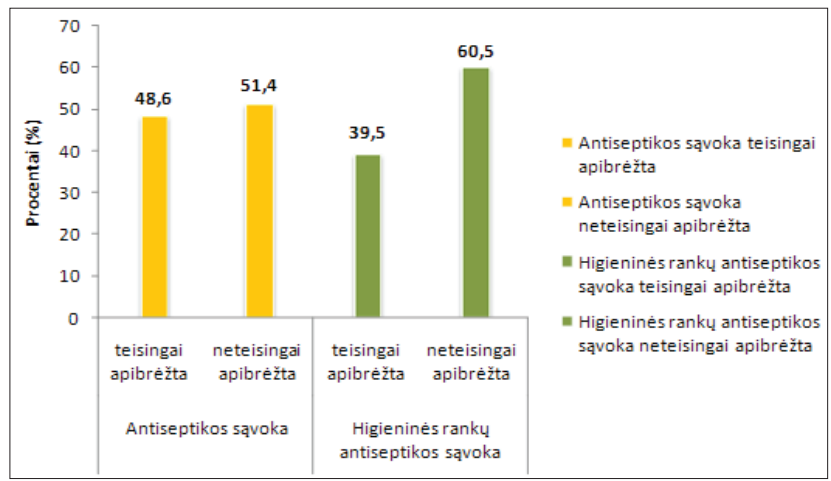

1 pav. Subjektyvi respondentų nuomonė apie antiseptikos ir higieninès rankų antiseptikos sąvokas
24 metų, max - 71 metų). Dauguma tyrime dalyvavusių respondentu buvo bendrosios praktikos slaugytojos $(40,3$ proc., $\mathrm{n}=98)$, kiek mažiau - bendrosios praktikos gydytojų (12,3 proc., $\mathrm{n}=30) .49,8$ proc. $(\mathrm{n}=121)$ tiriamujų darbo patirtis buvo daugiau nei 21 metai. Taip pat nemaža dalis $(21,8$ proc., $\mathrm{n}=53)$ respondentų turèjo $16-20$ metų darbo patirti. 85,6 proc. $(n=208)$ respondentų teisingai nurodè atvejus, kuomet reikia plauti rankas, t.y. prieš pradedant darbą, baigus kiekvieno ligonio apžiūrą, nusimovus pirštines, kurios buvo užterštos krauju ar biologiniais skysčiais bei prieš higieninę rankų dezinfekciją. Tyrimo metu nustatyta, kad 63,8 proc. $(n=155)$ respondentų rankoms plauti dažniausiai naudojo skystą muilą su dezinfekcinès medžiagos priedais.

Tyrime dalyvavusių respondentu buvo prašoma apibrèžti antiseptikos bei higieninès rankų antiseptikos sąvokas. 48,6 proc. $(n=118)$ apklausoje dalyvavusių respondentų teisingai apibrèžè antiseptikos ir 39,5 proc. $(n=96)$ higieninès rankos antiseptikos sąvokas (1 pav.).

68,7 proc. $(\mathrm{n}=167)$ tiriamujų nurodè, kad turi pakankamai žinių aseptikos/antiseptikos klausimais. Atlikus Spearman'o koreliaciją, vertinant ryši tarp respondentų darbo patirties bei tarp subjektyvios jų nuomonès aseptikos/ antiseptikos klausimais, nustatyta, kad kuo didesnè darbo patirtis, tuo respondentas turi daugiau žinių aseptikos/antiseptiklos klausimais $(r=-0,190 ; p=0,003) .70$ proc. $(n=21)$ bendrosios praktikos gydytojų nurode, kad turi pakankamai žinių aseptikos/antiseptikos klausimais, o 26,7 proc. $(n=8)$ - nepakankamai $\left(\chi^{2}=18,9 ; p=0,03\right) .73,5$ proc. $(n=72)$ bendrosios praktikos slaugytojų nurodè, kad turi pakankamai aseptikos/antiseptikos klausimais, 8,2 proc. $(n=8)-$ turi daug informacijos, o 18,4 proc. $(\mathrm{n}=18)$ - turi nepakankamai žinių aseptikos/antiseptikos klausimais.

Tyrimo metu nustatyta, kad 33,3 proc. $(\mathrm{n}=81)$ respondentų buvo susižeidę panaudota adata ar kitu aštriu instrumentu. Iš jų 28,4 proc. ( $n=23)$ nurodè, kad buvo susižeidę užteršta priemone, t.y. priemone, kontaktavusia su pacientu ar užterštu įrenginiu. 22,2 proc. $(n=18)$ respondentų teigè,

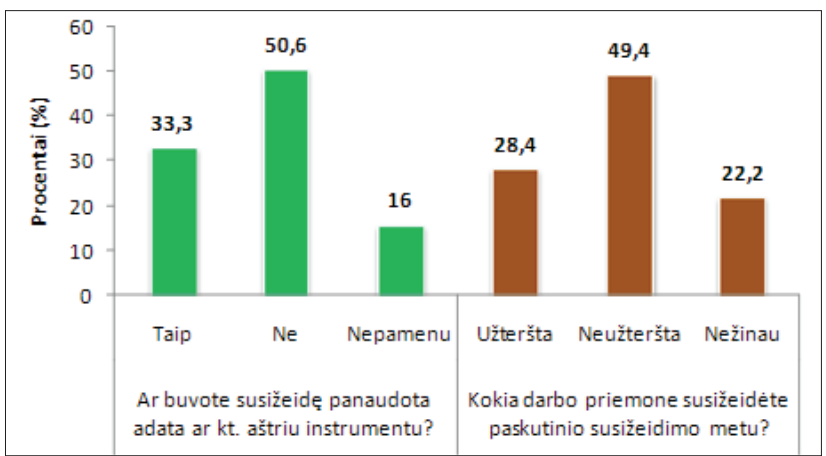

2 pav. Mikrotraumų dažnis tarp respondentų (procentai) 
kad nežino, ar priemonè, kuria susižeidè, buvo užteršta (2 pav.).

Nustatytas statistiškai reikšmingas skirtumas vertinant mikrotraumų dažnį tarp respondentų priklausomai nuo jų užimamų pareigų. 32,7 proc. $(\mathrm{n}=16)$ gydytojų specialistų nurodè, kad buvo susižeidę panaudota adata ar kitu aštriu instrumentu, o 51 proc. $(\mathrm{n}=25)$ - nepatyrè mikrotraumos. Tuo tarpu 42,9 proc. $(n=42)$ bendrosios praktikos slaugytojų nurodè, kad buvo susižeidusios panaudota adata ar kitu

1 lentelè. Mikrotraumų dažnis tarp respondentų priklausomai nuo jų užimamų pareigų

$\chi^{2}=13,90 ; p=0,003$

\begin{tabular}{|c|c|c|c|c|c|c|c|}
\hline \multirow{3}{*}{ Pareigos } & \multicolumn{4}{|c|}{ Mikrotraumos } & \multirow{3}{*}{ OR } & \multirow{3}{*}{ 95\% PI } & \multirow{3}{*}{$\mathrm{p}$} \\
\hline & \multicolumn{2}{|c|}{ Susižeidė } & \multicolumn{2}{|c|}{$\begin{array}{c}\text { Nesusižeidé, } \\
\text { nepamena }\end{array}$} & & & \\
\hline & $\mathbf{N}$ & Proc. & $\mathbf{N}$ & Proc. & & & \\
\hline $\begin{array}{l}\text { Bendrosios prak- } \\
\text { tikos slaugytoja }\end{array}$ & 42 & 51,8 & 56 & 34,5 & \multirow[t]{3}{*}{2,03} & \multirow[t]{3}{*}{$1,18-3,50$} & \multirow[t]{3}{*}{0,01} \\
\hline $\begin{array}{l}\text { Gydytojas speci- } \\
\text { alistas, bendro- } \\
\text { sios praktikos } \\
\text { gydytojas ir kt. }\end{array}$ & 39 & 48,1 & 106 & 65,4 & & & \\
\hline Iš viso & 81 & 100 & 162 & 100 & & & \\
\hline
\end{tabular}

2 lentelè. Mikrotraumų dažnis priklausomai nuo Poliklinikos skyriaus ${ }^{*} p=0,012$ - lyginant su Laboratorinès diagnostikos skyriuje dirbančiais darbuotojais $\chi^{2}=43,48 ; p=0,002$

\begin{tabular}{|c|c|c|c|c|c|c|c|c|}
\hline \multirow[t]{3}{*}{ Poliklinikos skyriai } & \multicolumn{6}{|c|}{$\begin{array}{c}\text { Ar buvote kada nors susižeidęs (-usi) } \\
\text { panaudota adata ar kitu aštriu in- } \\
\text { strumentu? }\end{array}$} & \multirow{2}{*}{\multicolumn{2}{|c|}{ Iš viso }} \\
\hline & \multicolumn{2}{|c|}{ Taip } & \multicolumn{2}{|c|}{$\mathrm{Ne}$} & \multicolumn{2}{|c|}{$\begin{array}{c}\text { Nepame- } \\
\text { nu }\end{array}$} & & \\
\hline & $\mathbf{N}$ & Proc. & $\mathbf{N}$ & Proc. & $\mathbf{N}$ & Proc. & $\mathbf{N}$ & Proc. \\
\hline Odontologijos skyrius & 17 & $47,2 *$ & 13 & 36,1 & 6 & 16,7 & 36 & 100 \\
\hline $\begin{array}{l}\text { Akušerijos ir gineko- } \\
\text { logijos skyrius }\end{array}$ & 2 & 16,7 & 3 & 25 & 7 & 58,3 & 12 & 100 \\
\hline Konsultacijų skyrius & 19 & 37,3 & 24 & 47,1 & 8 & 15,7 & 51 & 100 \\
\hline $\begin{array}{l}\text { Fizinès medicinos ir } \\
\text { ambulatorinės medi- } \\
\text { cininès reabilitacijos } \\
\text { skyrius }\end{array}$ & 7 & 38,9 & 9 & 50 & 2 & 11,1 & 18 & 100 \\
\hline $\begin{array}{l}\text { Psichikos sveikatos } \\
\text { centras }\end{array}$ & 4 & 21,1 & 15 & 78,9 & 0 & 0 & 19 & 100 \\
\hline $\begin{array}{l}\text { Infekcijų kontrolès } \\
\text { tarnyba }\end{array}$ & 0 & 0 & 1 & 50 & 1 & 50 & 2 & 100 \\
\hline $\begin{array}{l}\text { II Šeimos medicinos } \\
\text { skyrius }\end{array}$ & 6 & 23,1 & 19 & 73,1 & 1 & 3,8 & 26 & 100 \\
\hline $\begin{array}{l}\text { Šeimos ir vidaus ligu } \\
\text { skyrius }\end{array}$ & 8 & 38,1 & 11 & 52,4 & 2 & 9,5 & 21 & 100 \\
\hline $\begin{array}{l}\text { Laboratorinès dia- } \\
\text { gnostikos skyrius }\end{array}$ & 1 & 7,7 & 7 & 53,8 & 5 & 38,5 & 13 & 100 \\
\hline $\begin{array}{l}\text { Vaikų sveikatos prie- } \\
\text { žiūros skyrius }\end{array}$ & 10 & 41,7 & 10 & 41,7 & 4 & 16,7 & 24 & 100 \\
\hline Radiologijos skyrius & 7 & 33,3 & 11 & 52,4 & 3 & 14,3 & 21 & 100 \\
\hline
\end{tabular}

aštriu instrumentu, o 40,8 proc. $(\mathrm{n}=40)$ - nepatyrè mikrotraumos. Tyrimo metu nustatyta, kad su 2,03 karto didesniu šansu bendrosios praktikos slaugytojos patiria mikrotraumas nei kitų sričių specialistai (1 lentelè).

39,3 proc. $(n=11)$ respondentų, kuriu darbo patirtis iki 5 metų, nurodè, kad buvo susižeidę panaudota adata ar kitu aštriu instrumentu, o 46,4 proc. $(n=13)$ - nepatyre mikrotraumos. Tuo tarpu 32,1 proc. $(n=17)$ tiriamujų, kurie turejjo 16-20 metų darbo patirti, nurodè, kad buvo susižeidę panaudota adata ar kitu aštriu instrumentu, o 43,4 proc. $(\mathrm{n}=23)$ - nepatyre mikrotraumos. Bet statistiškai reikšmingo skirtumo tarp šių grupių nenustatyta $\left(\chi^{2}=11,88 ; \mathrm{p}=0,08\right)$.

Nustatytas statistiškai reikšmingas skirtumas vertinant mikrotraumų dažnį tarp respondentų priklausomai nuo to, kuriame skyriuje dirba respondentas. 47,2 proc. $(n=17)$ respondentų, dirbančių Odontologijos skyriuje, nurode, kad buvo susižeidę panaudota adata ar kitu aštriu instrumentu, o 36,1 proc. $(\mathrm{n}=13)$ - nepatyrè mikrotraumos. 41,7 proc. $(n=10)$ respondentų, dirbančių Vaikų sveikatos priežiūros skyriuje, nurode, kad buvo susižeidę panaudota adata ar kitu aštriu instrumentu, o 37,5 proc. $(\mathrm{n}=9)$ - nepatyrè mikrotraumos. Tuo tarpu dauguma kituose Poliklinikos skyriuose dirbančiu respondentų nurodè, kad nepatyrè mikrotraumos (2 lentelè).

40,7 proc. ( $\mathrm{n}=99$ ) Poliklinikos medicinos darbuotojų buvo pasiskiepiję hepatito B vakcina, o 2,9 proc. $(\mathrm{n}=7)$ - turejo nepilną vakcinacijos kursą. 75 proc. ( $\mathrm{n}=27)$ respondentų, kurie dirbo Odontologijos skyriuje, buvo pasiskiepiję (-usios) hepatito $B$ vakcina $\left(\chi^{2}=40,13 ; p<0,001\right)$. Tyrimo metu nustatyta, kad respondentai, dirbantys Odontologijos skyriuje, su 5,62 didesniu šansu dažniau skiepijasi nuo hepatito B nei respondentai, dirbantys kituose Poliklinikos skyriuose (OR=5,62; PI 95\%: 3,299,61; $<<0,001)$.

38,5 proc. $(\mathrm{n}=15)$ tiriamuju, kurie buvo pasiskiepiję hepatito B vakcina, nurodè, kad paskutinio susižeidimo metu susižeidè užteršta darbo priemone. Tuo tarpu 34,1 proc. $(n=14)$ respondentų, nurodžiusių, kad nèra pasiskiepiję nuo hepatito B, teigè, kad nežino ar priemone, kuria susižeidé, buvo užteršta ar ne (3 lentelè).

\section{Rezultatų aptarimas}

Tinkama rankų higiena yra kone svarbiausia infekcijų prevencijos priemonè, kad ji būtų efektyvi, labai svarbu užtikrinti sąlygas ir priemones jai at- 


\section{2}

likti $[3,12]$. Mūsų tyrimo duomenimis, 85,6 proc. $(n=208)$ respondentu teisingai nurodè atvejus, kuomet reikia plauti rankas. Baltijos regiono atsparumo antibiotikams tinklas - BARN (angl. Baltic antibiotic resistance collaborative network) $2011 \mathrm{~m}$. pabaigoje inicijavo projektą, kuriuo buvo siekiama pagerinti ligoninių personalo rankų higienos igūdžius. Projekte dalyvavo Lietuvos, Latvijos, Švedijos ir Rusijos (Sankt Peterburgo) ligoniniu gydytojai, slaugytojai bei slaugytojų padejejjai. Tyrimas atskleide, kad ligoniniu personalo žinios apie rankų higieną nèra pakankamos. Pavyzdžiui, ì klausimą „Kada būtina atlikti higieninę ranku antiseptiką?" teisingai atsakè 55,6 proc. respondentu [13]. Mūsų atlikto tyrimo metu nustatyta, kad 63,8 proc. $(n=155)$ respondentų rankoms plauti dažniausiai naudojo skystą muilą su dezinfekcinès medžiagos priedais. 2011-2012 m. ECDC vykdè hospitalinių infekcijų ir antimikrobinių vaistų vartojimo paplitimo tyrimą. Šio tyrimo metu nustatyta, kad Europos ligoninèse antiseptiko rankoms dezinfekuoti sunaudojama vidutiniškai 23,9 ml/1 lovadieniui. Sunaudojamo antiseptiko kiekis labai skiriasi tarp šalių: nuo mažiau nei $10 \mathrm{ml} /$ lovadieniui Bulgarijoje, Vengrijoje, Lietuvoje, Italijoje, Rumunijoje, Slovakijoje iki daugiau nei $50 \mathrm{ml} / \mathrm{lo}-$ vadieniui Danijoje, Graikijoje, Norvegijoje, Maltoje ir Švedijoje. Nustatyta, kad Lietuvoje rankų antiseptiko sunaudojama tik $6 \mathrm{ml} / 1$ lovadieniui, t. y. beveik 4 kartus mažiau nei vidutiniškai Europoje. Rodiklis truputi didesnis nei pirmus kartus matuojant rankų antiseptiko sunaudojimą Lietuvos ligoninèse, kuris $2008 \mathrm{~m}$. buvo 3,9 ml/lovadieniui, 2010 m. - $4 \mathrm{ml} /$ lovadieniui [13-14]. Mūsų tyrimo metu, nustatyta, kad 68,7 proc. $(\mathrm{n}=167)$ tiriamųjų turi pakankamai žinių aseptikos/antiseptikos klausimais.

Tyrimo metu nustatyta, kad 33,3 proc. $(\mathrm{n}=81)$ respondentų buvo susižeidę panaudota adata ar kitu aštriu instrumentu. Tyrimų duomenimis, Europoje adatomis susižalojama milijoną kartų per metus [15]. HBV infekcija yra vienas pavojingiausių medicinos darbuotojų profesinių veiksnių. Lietuvos sveikatos apsaugos darbuotojų profesinè sajunga

3 lentelè. Respondentų, patyrusių mikrotraumą, pasiskirstymas pagal pasiskiepijimą hepatito B vakcina ir kokia darbo priemone susižeidè paskutinio susižeidimo metu $\chi^{2}=13,25 ; p=0,04$

\begin{tabular}{|c|c|c|c|c|c|c|c|c|}
\hline \multirow{3}{*}{$\begin{array}{l}\text { Ar esate } \\
\text { pasiskiepijęs } \\
\text { (-usi) nuo } \\
\text { hepatito B? }\end{array}$} & \multicolumn{6}{|c|}{$\begin{array}{c}\text { Darbo priemonė, kuria susižeidė pa- } \\
\text { skutinio susižeidmo metu }\end{array}$} & \multirow{2}{*}{\multicolumn{2}{|c|}{ Iš viso }} \\
\hline & \multicolumn{2}{|c|}{ Užteršta } & \multicolumn{2}{|c|}{ Neužteršta } & \multicolumn{2}{|c|}{ Nežinau } & & \\
\hline & $\mathbf{N}$ & Proc. & $\mathbf{N}$ & Proc. & $\mathbf{N}$ & Proc. & $\mathbf{N}$ & Proc. \\
\hline Taip & 15 & 38,5 & 19 & 48,7 & 5 & 12,8 & 39 & 100 \\
\hline $\mathrm{Ne}$ & 6 & 14,6 & 21 & 51,2 & 14 & 34,1 & 41 & 100 \\
\hline $\begin{array}{l}\text { Nepilna vak- } \\
\text { cinacija }\end{array}$ & 1 & 100 & 0 & 0 & 0 & 0 & 1 & 100 \\
\hline Kita & 1 & 100 & 0 & 0 & 0 & 0 & 1 & 100 \\
\hline
\end{tabular}

2012 metais atliko sveikatos priežiūros įstaigų darbuotojų apklausą, siekdami išsiaiškinti darbuotojų patiriamą riziką ir susižeidimų (mikrotraumų) paplitimą, naudojantis aštriais instrumentais. 85 proc. respondentų, patyrusių miktrotraumas, apie tai atsakingųjų asmenų neinformavo ir neregistravo nelaimingo atsitikimo (incidento). Iš viso registruojama buvo tik 10 proc. visų mikrotraumų. 43 respondentams buvo atlikti kraujo tyrimai dèl virusiniu ligu po patirtų mikrotraumų darbe, 10 proc. iš jų buvo nustatyti šie susirgimai: 2 respondentams nustatytas hepatito $B$ virusas; 2 respondentams nustatytas hepatito $C$ virusas [18].

Mūsų vykdyto tyrimo metu nustatytas statistiškai reikšmingas skirtumas vertinant mikrotraumų dažni tarp respondentų priklausomai nuo jų užimamų pareigų $\left(\chi^{2}=13,90\right.$; $\mathrm{p}=0,003) .32,7$ proc. $(\mathrm{n}=16)$ gydytojų specialistu nurode, kad buvo susižeidę panaudota adata ar kitu aštriu instrumentu, o 51 proc. $(\mathrm{n}=25)$ - nepatyrè mikrotraumos. Tuo tarpu 42,9 proc. $(n=42)$ bendrosios praktikos slaugytojų nurode, kad buvo susižeidusios panaudota adata ar kitu aštriu instrumentu, o 40,8 proc. ( $n=40)$ - nepatyre mikrotraumos. Nustatyta, kad su 2,03 karto didesniu šansu bendrosios praktikos slaugytojos patiria mikrotraumas nei kitų sričių specialistai (OR=2,03; PI 95\%: 1,18-3,50; $\mathrm{p}=0,01) .2006$ $\mathrm{m}$. Kauno medicinos universiteto kliniku atlikto tyrimo metu nustatyta, kad daugiau kaip pusè $-51,4$ proc. $(n=160)$ respondentų per tiriamaji laikotarpi patyre mikrotraumą. Visais mikrotraumų atvejais buvo sužeisti rankų pirštai. Statistiškai reikšmingai $(p<0,05)$ dažniau mikrotraumas patiria slaugytojos $(64,5$ proc.) ir gydytojai $(52,7$ proc.) nei pagalbiniai darbuotojai (31,7 proc.). Užsienio tyrimų duomenimis, slaugytojos dažniausiai susižeidžia injekcinėmis adatomis: EPINET tyrimo duomenimis - 72 proc. mikrotraumų sudare ịsidūrimas injekcinėmis adatomis, Kanadoje 2000-2004 m. atlikto tyrimo duomenimis $-63,67$ proc. medicinos darbuotojų, patyrusių mikrotraumas, susižeidè injekcinèmis adatomis [16-17].

Lietuvoje medicinos darbuotojų sergamumas hepatitu B vidutiniškai 5 kartus didesnis už bendrą gyventojų sergamumą [19-20]. Šiaurès Europoje hepatito B viruso seruminių žymenų paplitimas tarp medicinos darbuotojų sudaro 10 proc., Vidurio Europoje - 20 proc., Pietų Europoje - 40 proc. [21]. Lietuvoje atliktų mokslinių tyrimų duomenimis, vidutinis HBV infekcijos žymenų paplitimas medicinos darbuotojų grupeje sudaro 29 proc. Seropozityvių gydytojų nustatyta 30,4 proc., slaugytoju - 31,8 proc., slaugytojos padejejjų - 8,3 proc. [22]. Mūsų atlikto tyrimo metu nustatyta, kad 55,1 proc. ( $\mathrm{n}=134)$ Poliklinikos medicinos darbuotojų nebuvo pasiskiepiję hepatito B vakcina. 40,7 proc. $(n=99)$ respondentų nurodè, kad buvo pasiskiepiję hepatito $B$ vakcina, o 2,9 proc. $(n=7)$ - turèjo nepilną vakcinacijos 
kursą. 75 proc. $(\mathrm{n}=27)$ respondentų, kurie dirbo Odontologijos skyriuje, buvo pasiskiepiję (-usios) hepatito B vakcina $\left(\chi^{2}=40,13 ; p<0,001\right)$. Tyrimo metu nustatyta, kad respondentai, dirbantys Odontologijos skyriuje, su 5,62 didesniu šansu dažniau skiepijasi nuo hepatito $B$ nei respondentai, dirbantys kituose Poliklinikos skyriuose (OR=5,62; PI 95\%: 3,29-9,61; $<<0,001)$. Tuo tarpu $2006 \mathrm{~m}$. Kauno medicinos universiteto kliniku atlikto tyrimo metu nustatyta, 86 proc. tyrime dalyvavusių darbuotojų buvo nepasiskiepiję hepatito B vakcina. 4 proc. atliktas ne visas vakcinacijos kursas ir tik 10 proc. atliktas visas vakcinos kursas [10].

Kabulo ligoninèse atliktas tyrimas parode, kad odontologai patenka tarp penkių dažniausiai darbe patiriančių mikrotraumas specialybių (apie 75 proc. odontologų buvo susižeidę aštriais instrumentais) [23]. Vokietijoje atlikto tyrimo duomenimis, bendrosios praktikos gydytojai odontologai buvo dažniau susižeidę nei burnos chirurgai (atitinkamai, 36,2 proc. ir 19,6 proc.) [24].

\section{Išvados}

Daugiau nei pusé tyrime dalyvavusių respondentų turi pakankamai žinių infekcijų kontrolès klausimais, t.y. rankų higienos, dezinfekcijos, sterilizacijos klausimais.

33,3 proc. respondentų buvo susižeidę panaudota adata ar kitu aštriu instrumentu. Iš jų 28,4 proc. nurodè, kad buvo susižeidę užteršta priemone, t.y. priemone, kontaktavusia su pacientu ar užterštu įrenginiu. Dažniausiai mikrotraumas patiria bendrosios praktikos slaugytojos, vertinant pagal skyrių - respondentai, dirbantys Odontologijos skyriuje.

Daugiau nei pusé tiriamujų nebuvo pasiskiepiję hepatito B vakcina. Respondentai, dirbantys Odontologijos skyriuje, su 5,62 didesniu šansu dažniau skiepijasi nuo hepatito B nei respondentai, dirbantys kituose Poliklinikos skyriuose.

\section{Literatūra}

1. Burke J. Infection control - a problem for patient safety. New England Journal of Medicine 2003;348:651-657.

https://doi.org/10.1056/NEJMhpr020557

2. Gastmeier P, Coignard B, Horan T. Surveillance for healthcare - associated infections. Infectious Disease Surveillance. Blackwell Publishing 2007:159-170. https://doi.org/10.1002/9780470692097.ch13

3. WHO Guidelines on Hand Hygiene in Healthcare. First Global Patient Safety Challenge Clean Care is Safer Care Prieiga: http:// apps.who.int/iris/bitstream/10665/44102/1/9789241597906_ eng.pdf

4. Annual epidemiological report on communicable diseases on Europe 2008. European Centre for Disease Prevention and Control 2008:16-18.
5. Markevičė R. Infekcijų prevencijos ligoninèse veiklos vertinimo indikatoriai, ES šalių patirties išbandymas Lietuvoje. Prieiga: http://www.hi.lt/uploads/news/id388/3.pdf

6. Užkrečiamųjų ligų ir AIDS centras. Sergamumo ūminiais virusiniais hepatitais B ir C tendencija Lietuvoje 1993-2015 m. Prieiga: http://www.ulac.lt/uploads/downloads/Sergamumas\%20VHB_VHC_2015_12_31.pdf

7. Čaplinksas S., Liausėdienė K., Čaplinskienė I., Nagys Z. Gyventojų informuotumas apie užkrečiamąsias ligas. Lietuvos bendrosios praktikos gydytojas, 2015 m. gruodis; 19(10).

8. European Centre for Disease Prevention and Control. Hepatitis B and C surveillance and epidemiology in Europe. 2012. http:// ecdc.europa.eu/en/publications/Publications/hepatitis-b-c-surveillance-europe-2012-july-2014.pdf

9. Lietuvos Respublikos sveikatos apsaugos ministro $2004 \mathrm{~m}$. spalio 14 d. ịsakymas Nr. V-716 Dèl darbuotoju, kurie skiepijami darbdavio lëšomis, profesijų ir pareigybių sąrašo patvirtinimo" (Žin., 2004; 155-5664).

10. Gailienė G., Cenenkienė R. Medicinos darbuotojų profesiniai biologiniai rizikos veiksniai. Kauno medicinos universiteto klinikos. Medicina, 2009; 45(7).

11. Wenzel RP. Occupational exposure to blood-borne pathogens: epidemiology and prevention. In: Prevention and control of nosocomial infections. 4th ed. USA: The Williams \& Wilkins Co 2002; 430-66.

12. Lietuvos Respublikos sveikatos apsaugos ministro $2012 \mathrm{~m}$. spalio 19 d. įsakymas Nr. V-946 dèl Lietuvos higienos normos 47-1:2012, ,Sveikatos priežiūros įstaigos. Infekcijų kontrolès reikalavimai" patvirtinimo (Valstybès žinios, 2012-10-25; 1246241).

13. Markevičè R. Tinkama rankų higiena-svarbu, suprantama, bet ar visada laikomès?. Higienos institutas. SLAUGA. Mokslas ir praktika, 2014; 2 (206).

14. European Centre for Disease Prevention and Control. Point prevalence survey of healthcare associated infections and antimicrobial use in Europe acute care hospitals 2011-2012.

15. International Healthcare Worker Safety Center. EPINET. Prieiga: https://www.medicalcenter.virginia.edu/epinet/epinetdatareports.html

16. Excellence reference of management of occupational exposures to HIV. MMWR 1995;44:929.

17. Hong Z, Nguyen M, Paton S, Wu J. Canadian needle stick surveillance network (2000-2004). J Hosp Infect 2006; Suppl 1:9-11. https://doi.org/10.1016/s0195-6701(06)60033-9

18. Su(si)žeidimų aštriais instrumentais Lietuvos sveikatos priežiūros ịstaigose 2012 metų apklausos rezultatai. Lietuvos sveikatos apsaugos darbuotojų profesinė sajunga, Aldona Baublyte. Užkrečiamųjų ligų ir AIDS centras. Infekcijų valdymas sveikatos priežiūros ịstaigose. Programa ir tezių knyga, 2013 m. Prieiga: http://www.ulac.lt/uploads/downloads/leidiniai/ teziu_k_infekciju_09.pdf

19. Norkienė S., Sąlyga J., Jankauskienė V., Dimaitė E. Hemodia- 
lizès skyriuje dirbančių medicinos darbuotojų rizikos veiksnių ir jų įtakos sveikatai analizè. Sveikatos mokslai. 2014; 24 (4):106-110 https://doi.org/10.5200/sm-hs.2014.076

20. Ambrozaitis A, Žagminas K. Virusiniai hepatitai. Vilnius. Vilniaus universitetas, 1997:139-150.

21. Damme V. Hepatitis B - still a global problem. Viral hepatitis, 1995;3:4-7.

22. Žagminas K., Ambrozaitis A., Balčiūnienė L., Matvejevienè M., Matuzevičienė V., Barkus M., Bakasènas V. Hepatito B viruso infekcijos seruminių žymenų paplitimas tarp medicinos darbuotojų. Visuomenès sveikata, 2003;4(23):23-26.

23. Salehi AS, Garner P. Occupational injury history and universal precautions awareness: a survey in Kabul hospital staff. BMC Infect Dis. 2010;10:19-22.

https://doi.org/10.1186/1471-2334-10-19

24. Wicker S, Rabenau HF. Occupational exposures to bloodborne viruses among German dental professionals and students in a clinical setting. Int Arch Occup Environ Health. 2010;83:77-83. https://doi.org/10.1007/s00420-009-0452-3

\section{MEDICAL STAFF KNOWLEDGE ABOUT INFECTION CONTROL IN HEALTHCARE INSTITUTIONS}

J. Kairys, R. Šturienė, M. Lamanauskaitė, V. Dobrovolskij

Key words: medical staff, hepatitis B, sharps injury, infection control, knowledge.

\section{Summary}

The aim of study - to evaluate medical staff knowledge about infection control, to clarify scope of vaccination against hepatitis B and to establish prevalence of sharps injury among medical staff in public institution Šeškinès Clinic. It was carried out medical staff questionnaire survey. The Questionnaire consisted of questions on hand hygiene, disinfection, sterilization, sharps injury and vaccination of hepatitis B. 305 questionnaires were distributed and 251 was collected (response rate 82.3 percent.), the 243 were used in the study. 68.7 percent of respondents have sufficient knowledge of asepsis / antisepsis issues. 33.3 percent of medical staff were injured used needle or other sharp instrument, 28.4 percent of them indicated that they were injured contaminated equipment. The results of the study showed that the chance of sharps injury for general practice nurses 2.03 times higher than for other professionals. 40.7 percent of respondents indicated that they were vaccinated for hepatitis B. Medical staff working in the dental section have 5.62 higher chance to be vaccinated for hepatitis B than medical staff in other divisions.

Correspondence to: relia@smc.lt

Gauta 2016-10-26 